\title{
PENGGUNAAN MEDIA JARIMATIKA UNTUK MENINGKATKAN KEMAMPUAN BERHITUNG ANAK USIA DINI
}

\author{
Nurlaela \\ UIN Sunan Kalijaga Yogyakarta \\ Email:nlaela009@gmail.com
}

\begin{abstract}
Early childhood is one of the important stages in a person's life, which greatly affects the next stage of development. Therefore, at this time, more attention is needed to the existing aspects of development. The aspect of cognitive development is one of the important aspects to be maximally developed from an early age. One of the cognitive aspects development can be done through the use of an educational game, Jarimatika. The use of Jarimatika makes it easy for teachers to introduce the concept of counting to children. Jarimatika educational game tools have been implemented properly according to direct observation and can be said to be "done". The results of the use of Jarimatika educational play tools to improve early childhood numeracy skills were obtained during the research, namely $\mathrm{BSH}$, which means developing according to expectations, children can do it themselves without any help from their teacher, BSB which means developing very well, children have done it independently and can help the theme is in carrying out activities or tasks.
\end{abstract}

Key words: alat permainan edukatif, jarimatika, kemampuan berhitung

\begin{abstract}
Abstrak: Masa usia dini merupakan salah satu tahap penting dalam kehidupan seseorang, yang sangat mempengaruhi tahap perkembangan selanjutnya. Oleh karena itu pada masa ini diperlukan perhatian lebih pada aspek-aspek perkembangan yang ada.Aspek perkembangan kognitif merupakan salah satu aspek yang penting dikembangkan secara maksimal sejak usia dini. Pengembangan aspek kognitif salah satunya dapat dilakukan melalui penggunaan alat permainan edukatif jarimatika. Penggunan jarimatika memudahkan guru untuk mengenalkan konsep berhitung pada anak. Alat permainan edukatif jarimatika sudah diterapkan dengan baik sesuai pengamatan langsung dan dapat dikatakan "terlaksana". Hasil penggunaan alat bermain edukatif jarimatika untuk meningkatkan kemampuan berhitung anak usia dini diperoleh saat penelitian yaitu BSH yang artinya Berkembang Sesuai Harapan, anak sudah dapat melakukan sendiri tanpa ada bantuan dari gurunya, BSB yang artinya Berkembang sangat Baik, anak sudah melakukannya secara mandiri serta dapat membantu temanya dalam melaksanakan kegiatan atau tugas.
\end{abstract}

Kata kunci: alat permainan edukatif, jarimatika, kemampuan berhitung

\section{PENDAHULUAN}

Pendidikan anak usia dini sangat perlu memperhatikan unsur-unsur yang akan mempengaruhi perkembangan anak, agar anak mampu berkembang dengan optimal. Lembaga harus memiliki stategi 
Nurlaela, Penggunaan Media Jarimatika Untuk Meningkatkan Kemampuan Berhitung Anak Usia Dini

pembelajaran yang dapat mengoptimalkaan perkembangan anak, stategi yang digunakan harus sesuai dengan tingkatan usia anak.

Pendidikan anak usia dini yaitu suatu upaya pembinaan yang ditunjukan kepada anak seja lahir hingga usia anak enam tahun yang dilakukan melalui pemberian rangsangan untuk membantu pertumbuhan, perkembangan jasmani dan rohani agar anak memilki kesiapan untuk memasuki pendidkan lebih lanjut ${ }^{1}$.

Masitoh mengungkapkan bahwa Pendidikan di Taman Kanak-Kanak merupakan salah satu bentuk pendidikan anak usia dini yang memiliki peranan sangat penting untuk mengembangkan kepribadian anak serta mempersiapkan mereka memasuki jenjang pendidikan selanjutnya. Pendidikan Taman Kanak-Kanak memberi kesempatan untuk mengembangkan kepribadian anak, oleh karena itu pendidikan untuk anak usia dini khususnya di Taman Kanak-Kanak perlu menyediakan berbagai kegiatan yang dapat mengembangkan berbagai aspek perkembangan anak $^{2}$. Belajar di taman kanak-kanak yang mengembangkan aspek perkembangan melaksanakan kegiatan bermain sambil belajar dikarenakan anak belum sepenuhnya menyadari pentingnya sekolah. Dalam masa prasekolah, daya pikir anak masih bersifat imajinatif, berangan-angan (berkhayal), berbeda dengan usia SD yang daya pikirnya sudah berkembang ke arah berpikir kongkrit. ${ }^{3}$ Menurut Hikmah anak usia dini merupakan fundamental bagi kehidupan anak. Masa ini merupakan masa emas dimana anak mulai peka untuk menerima rangsangan dan otak mengalami pertumbuhan serta perkembangan yang sangat pesat. Oleh karena itu memberikan perhatian lebih terhadap anak usia dini merupakan bentuk sikap wujud perhatian diantaranya memberikan pendidikan baik langsung maupun melalui lembaga pendidikan anak usia dini. Setiap anak

\footnotetext{
${ }^{1}$ Mursid. 2015. Pengembangan Pembelajaran PAUD. Bandung: PT. Remaja Rosdakarya, hal. 37

2 Masitoh, dkk. 2005. Strategi Pembelajaran TK. Jakarta: Universitas Terbuka, hal. 2

3 Joni. (2016). Peningkatan Kemampuan Kognitif Anak dalam Kegiatan Berhitung dengan Permainan Dadu TK Mutiara Pekanbaru. Jurnal PAUD Tambusai, 2(1), 1-10.
} 
memiliki aspek perkembangan yang berbeda-beda, beberapa aspek perkembangan yang harus anak capai diantaranya nilai agama dan moral, fisik motorik, kognitif, sosial emosional, bahasa dan seni, aspek perkembangan yang akan dibahas dalam penelitian ini yaitu aspek perkembangan kognitif. ${ }^{4}$ Dalam pedoman pembelajaran bidang pengembangan kognitif di Taman Kanak-Kanak, (2007) disebutkan bahwa pengembangan kognitif adalah suatu proses berpikir berupa kemampuan untuk menghubungkan, menilai dan mempertimbangkan sesuatu. Dapat disimpulkan perkembangan kogtif kemampuan untuk memecahkan suatu masalah, Salah satu aspek dalam pengembangan kognitif ini adalah pengembangan pembelajaran matematika. Praktek-praktek pembelajaran matematika untuk anak usia dini di berbagai lembaga pendidikan anak usia dini baik jalur formal maupun jalur nonformal sudah sering dilaksanakan.

Konsep matematika tidak akan pernah hilang dalam kehidupan seharihari. Matematika adalah ilmu dasar yang sangat berguna dan banyak memberikan kontribusi dalam kehidupan manusia. Secara bahasa "Matematika" berasal dari perkataan Yunani, yaitu "mathematike" yang berarti mempelajari. Perkataan itu berasal dari kata "mathema" yang berarti pengetahuan atau ilmu. Kata mathematike berhubungan pula dengan kata lainnya yang hampir sama, yaitu mathein yang berarti belajar (berpikir). Dengan demikian, matematika berarti ilmu pengetahuan yang diperoleh dengan cara berpikir atau bernalar. Hal ini berarti matematika lebih menekankan aktivitas dalam dunia penalaran ${ }^{5}$.

Metode pembelajaran mempunyai peran yang sangat penting terhadap berhasil dan tidaknya tujuan pendidikan karena, tanpa metode pembelajaran yang menarik maka pembelajaran tidak akan berhasil

\footnotetext{
${ }^{4}$ Hikmah, Q., Lathif, M. A., \& Khutobah, K. (2016). Peningkatan Kemampuan Berhitung Pada Anak Kelompok B Melalui Permainan Kartu Angka di TK Dharma Indria I Kecamatan Patrang Kabupaten Jember Tahun Pelajaran 2015/2016. Jurnal Edukasi UNEJ, 3(2), 39-42. https://doi.org/10.19184/jukasi.v3i2.3528.
}

${ }^{5}$ Erman S., dkk. 2003. Strategi Pembelajaran Matematika Kontemporer. JICA: UPI, hal. 15-16 
Nurlaela, Penggunaan Media Jarimatika Untuk Meningkatkan Kemampuan Berhitung Anak Usia Dini

dengan baik. Pemilihan metode yang akan digunakan harus relevan dengan tujuan penguasaan konsep, transisi dan lambang dengan berbagai variasi materi, media dan bentuk kegiatan yang akan dilakukan. Kemampuan yang diharapkan dalam stimulasi berhitung di pada anak usia dini dapat dilaksanakan melalui penguasaan konsep, transisi dan lambang yang terdapat disemua jalur matematika, yang meliputi pola, klasifikasi bilangan, ukuran geometri estimasi dan statistika. ${ }^{6}$

Metode jari merupakan metode berhitung yang muncul sebagai salah satu bentuk penyelesain untuk masalah matematika. Tribudiyono dalam Sulistyaningsih (2018) menyatakan bahwa jarimatika adalah metode berhitung dengan menggunakan sepeluh jari tangan, jari matika mengajarkan kepada setiap anak bahwa matematika (khususnya berhitung) itu menyenagkan. Jarimatika sangat mudah untuk dilaksanakan karena anak mengalami sendiri menghitung menggunakan jari-jari mereka. Oleh karena itu metode ini akan lebih menarik apabila diterapkan sebagai salah satu metode pembelajaran karena peserta diidk akan mengikuti pembelajaran dengan sangat aktif sesuai tahap perkembangan kognitif.

Dari penjelasan di atas maka peneliti tertarik untuk menggunakan salah satu metode pembelajaran permainan jari sebagai media pembelajaran yang efektif untuk meninkatkan kemampuan berhitung peserta didik. $^{7}$

\section{METODE PENELITIAN}

Jenis dan penelitian ini menggunakan pendekatan deskriptif kualitatif, Menurut Sugiyono deskriftif kualitatif adalah metode penelitian yang

\footnotetext{
${ }^{6}$ Depdiknas 2007. Pedoman Permainan Berhitung Permulaan di Taman KanakKanak. Jakarta: Dirjen Dikdasmen.
}

7 Sulistyaningsih, N. (2018). Peningkatan Keaktifan Belajar Matematika dengan Strategi Pembelajaran. Jurnal Pendidikan: Riset \& Konseptual, 2(1), hal. 57-63. 
digunakan untuk peneliti pada kondisi obyek yang alamiah, dimana peneliti merupakan kunci instrumen, teknik pengumpulan data dilakukan secara trigulasi (gabungan), analisis data bersifat iduktif/kualitatif, serta hasil kualitatif lebih menekankan pada makna dari generalisasi.

Penelitian ini dilakukan di RA Baiturrahman Bima Cirebon. Penelitian dilaksanakan melalui beberapa prosedur yakni pra penelitian, perencanaan, pengumpulan data, analisis dan pengolahan data, verifikasi hasil penelitian, penyimpulan dan rekomendasi. Adapun subjek dalam penelitian ini yakni 42 siswa dan melibatkan 5 guru, meliputi siswa kelas $A$ dan kelas B. Penelitian ini dilakukan selama satu bulan melalui delapan kali penerapan.

Pengumpulan data dilakukan melalui wawancara, observasi, dan dokumentasi. Sedangkan analisis data dilakukan melalui tahap triangulasi yakni reduksi data, penyajian data, dan penarikan kesimpulan atau verifikasi ${ }^{8}$.

Jenis sumber data penelitian ini adalah sebagai berikut:

1. Sumber data primer adalah sumber data yang langsung memberikan data kepada pengumpul data. Sumber data dalam penelitian ini adalah kepala sekolah, guru kelas, guru pendamping, dan orang tua.

2. Sumber data Sekunder adalah sumber data yang tidak langsung memberikan data kepada pengumpul data, misalnya lewat orang lain dan lewat dokumen ${ }^{9}$. Sumber data sekunder penilitian ini mengambil lewat orang lain atau dokumen-dokumen maupun buku yang membahas judul penelitian ini sebagai acuan rujukan dan menganalisis. Sumber data sekunder adalah yang berasal dari tangan kedua yaitu data yang diperoleh dari pihak lain, tidak diperoleh secara langsung

${ }^{8}$ Sugiyono. (2014). Metode Penelitian Kuantitatif, Kualitatif, dan R\&D. Bandung: Alfabeta, hal. 14

${ }^{9}$ Sugiyono. 2014.Op.cit, hal. 14 
oleh peneliti dari subjek penelitian misalnya seperti: masyarakat, lingkungan sekolah, buku pustaka, artikel, dan dokumentasi ${ }^{10}$.

Instrumen yang digunakan dalam penelitian ini adalah catatan lapangan atau lembar observasi, yaitu catatan tertulis yang didengar, dilihat, dialami, dan dipikirkan dalam rangka pengumpulan data yang refleksi terhadap data dalam penelitian ini $^{11}$.

\section{KERANGKA TEORI}

\section{Alat Permainan Edukatif}

Alat Permainan Edukatif adalah bentuk alat atau sarana bermain yang memiliki nilai-nilai pendidikan di dalamnya. Bermain merupakan rangkaian kegiatan atau aktivitas anak untuk bersenang-senang. Apapun kegiatannya, selama itu terdapat unsur kesenangan atau kebahagiaan bagi anak usia dini maka bisa disebut sebagai bermain. Permainan itu sendiri dapat dilakukan dengan menggunakan alat atau tanpa alat. Permainan merupakan sesuatu yang digunakan dan dijadikan sebagai sarana aktivitas bermain. Oleh karena itu, permainan ini ragamnya sangat banyak mulai yang tradisional sampai pada yang modern.

Dalam konteks ini yang sangat penting menjadi perhatian adalah mengenai pentingnya bermain bagi anak usia dini, lebih-lebih untuk menanamkan nilai-nilai karakter. Ada beberapa alasan yang menyebutkan tentang perntingnya bermain bagi anak usia dini, di antaranya $^{12}$ :

\footnotetext{
${ }^{10}$ Saifuddin Azwar. 2009. Metode Penelitian. Yogyakarta: Pustaka Pelajar, hal. 56

${ }^{11}$ Sanjaya, W. 2013. Strategi Pembelajaran Beorientasi Standar proses Pendidikan. Jakarta: Kencana, hal. 77.

12 M. Fadlillah. 2016. Penanaman Nilai-Nilai Karakter Pada Anak Usia Dini Melalui PermainanPermainan Edukatif. Prosiding Seminar Nasional Pengintegrasian Nilai Karakter dalam Pembelajaran Kreatif di Era Masyarakat Ekonomi ASEAN., hal. 4
} 
a. Menurut ahli pendidikan anak, cara belajar anak yang paling efektif adalah melalui bermain atau permainan. Dengan demikian bermain anak dapat meningkatkan penalaran dan memahami keberadaannya di lingkungan teman sebaya dan membentuk daya imajinasi.

b. Melalui bermain anak dapat mempelajari dan belajar banyak hal, dapat mengenal aturan, bersosialisasi, kerjasama, disiplin, dan sebagainya.

c. Bermain adalah cara yang paling baik dan tepat untuk mengembangkan kemampuan anak usia dini.

\section{Macam-Macam Permainan Edukatif Anak Usia Dini}

Permainan atau alat permainan edukatif anak usia dini memiliki banyak ragam yang dapat dijadikan sebagai media untuk menanamkan nilai-nilai karakter pada anak usia dini. Alat permainan edukatif dapat digunakan untuk penanaman nilai-nilai karakter. Adapun macam permainan atau alat permainan edukatif yang dimaksud sebagai berikut:

a. Permainan Balok

Permainan Balok adalah bentuk alat permainan edukatif yang terdiri dari potongan-potongan balok dengan berbagai bentuk, warna dan ukuran. Alat permainan ini biasanya terbuat dari kayu yang keras dan kuat. Permainan balok sangat cocok digunakan untuk anak usia dini. Model dan jenisnya Ppermainan balok sangat banyak ragamnya. Permainan balok ini paling banyak digunakan di lembaga PAUD, karena memang permainan balok sangat disenangi oleh anak. Adapun cara menggunakan alat permainan balok yaitu dengan menyusun balok-balok tersebut sesuai imajinasi yang ada pada diri anak misalnya membuat istana, rumah-rumahan, dan bentuk lain yang dikehendaki. Permainan balok ini memiliki banyak manfaat bagi perkembangan anak, di antaranya: untuk menstimulasi 
Nurlaela, Penggunaan Media Jarimatika Untuk Meningkatkan Kemampuan Berhitung Anak Usia Dini

motorik halus anak, imajinasi, kreativitas, daya konsentrasi, mengenal warna dan berbagai macam bentuk geometri. ${ }^{13}$

b. Jarimatika

Slameto (2010) menyebutkan bahwa metode pengajaran adalah suatu cara ataupun jalan yang harus digunakan oleh pendidik yang bertujuan untuk mendapatkan pengetahuan, sikap, kecakapan dan keterampilan siswa dalam proses belajar. Metode merupakan salah satu faktor yang dapat menunjang keberhasilan dalam tujuan pembelajaran. Semakin mudah metode yang digunakan maka semakin mudah pula untuk diterapkan, sehingga lebih mudah diserap dan peluang membuat kesalahan juga semakin kecil. Dan sebaliknya, semakin susah dan rumit metode yang digunakan, maka akan semakin lambat dan peluang membuat kesalahan akan semakin besar. Selain itu, metode juga harus disesuaikan dengan materi pelajaran serta karakteristik siswa. ${ }^{14}$

Jarimatika adalah cara berhitung cepat dan mudah dikerjakan dalam operasi kabataku (kali, bagi, tambah, kurang). Menurut Prasetyono jarimatika merupakan salah satu teknik menghitung cepat dan akurat yang paling berkembang pesat dan sangat diminati. Christine (2013) menjabarkan keisitimewaan dalam metode jarimatika yang tidak dimiliki oleh metode yang lain adalah: "1) memberikan visualisasi proses berhitung, hal ini akan membuat anak mudah melakukannya; 2) menggembirakan anak saat digunakan; 3) tidak memberatkan memori otak anak; 4) alatnya gratis, selalu dibawa dan tidak dapat disita."15 Jarimatika menurut Septi Peni Wulandari jarimatika adalah "metode menghitung dengan

\footnotetext{
${ }^{13} \mathrm{Ibid}$, hal. 5

${ }^{14}$ Slameto. 2010. Belajar dan Faktor-Faktor Yang Mempengaruhinya. Jakarta: PT. Rineka Cipta.

${ }^{15}$ Nasution, T. K., \& Surya, E. (2015). Penerapan Teknik Jarimatika dalam Upaya Meningkatkan Kemampuan Operasi Hitung Perkalian Bilangan. Edumatica, 05(02), 49-58
} 
menggunakan jari tangan". Jarimatika adalah sebuah metode sederhana dan menyenangkan mengajarkan berhitung dasar kepada anak-anak menurut kaidah: dimulai dengan memehamkan secara benar terlebih dahulu tentang konsep bilangan, lambang bilangan, dan operasi hitung dasar, kemudian mengajarkan cara berhitung jari-jari tangan. Prosesnya diawali, dilakukan dan diakhiri dengan gembira. ${ }^{16}$

Adapun bahan-bahan untuk membuat jarimatika ini yaitu sterofom, lem, tutup botol, kertas asturo, dan perekat. Adapun cara membuat alat permainan edukatif jarimatika ini adalah:

a) Membuat pola jari.

b) Membuat lingkaran dari kertas dan ditempel angka-angka.

C) Membuat pola dadu.

d) Membuat pola lambang + dan =

e) Setelah sudah membuat pola jari dan dan bentuk pola angkaangka, lalu tempel pola jari-jari di atas sterofom lalu setiap jari-jari diberi perekat.

f) Lalu tempel tutup botol dan lambang bilangan + dan $=$

g) Lalu tempel angka-angka dari 1 hingga 12.

Adapun cara menggunakan alat permainan jarimatika ini yaitu dengan mengkocok dadu, ketika dadu sudah dikocok dan sudah terlihat nilai yang didapat maka anak mengambil angka yang didapat saat pengkocokkan dadu, kemudian ditempel ai atas tutup botol, lalu anak-anak melipat jari-jari dengan menyisakan jari yang berdiir sesuai nilai yang dikocok oleh anak, kemudian anak mengocok dadu kembali seperti awal, dan kemudian anak menghitung jari yang masih berdiri dan anak dapat mudah berhitung dengan alat permainan jarimatika tersebut. Permainan jarimatika ini memiliki banyak manfaat bagi perkembangan anak, di antaranya: untuk

${ }^{16}$ Sulistiyaningsih, Ibid, hal. $57-63$ 
memudahkan anak dalam berhitung dan mengenal angka-angka pada anak.

\section{Kemampuan Berhitung}

Sulistiyaningsih (2008) mengungkapkan bahwa kegiatan berhitung untuk anak usia dini disebut juga sebagai kegiatan menyebutkan urutan bilangan atau membilang buta (route counting/rational counting). Anak menyebutkan urutan bilangan tanpa menghubungkan dengan bendabenda konkrit. Pada usia 4 tahun mereka dapat menyebutkan urutan bilangan sampai sepuluh. Sedangkan usia 5 atau 6 tahun dapat menyebutkan bilangan sampai seratus.

Berhitung juga memiliki manfaat yang sangat besar, adapun manfaat berhitung awal adalah sebagai berikut:

a. Mengoptimalkan fungsi otak. Pembelajaran berhitung awal terbukti sangat berguna dalam mengoptimalkan fungsi-fungsi otak (otak kanan khususnya) yang meliputi daya analisa, ingatan, logika, visi, kemandirian, ketekunan, penemuan dan penerapan. Dengan memahami disiplin dasar eksakta ini, manusia diharapkan dapat menguasai dan menggunakan secara optimal seluruh potensi dan kreativitas yang ada dalam menyerap ilmu-ilmu yang tentunya akan bermanfaat dalam kehidupannya sehari-hari.

b. Melatih daya imajinasi dan kreativitas, logika, sistematika berfikir, daya konsentrasi dan daya ingat. Ini dicapai dengan melatih otak kiri dan kanan menjadi lebih aktif melalui pembelajaran berhitung.

c. Meningkatkan kecepatan, ketepatan dan ketelitian dalam berfikir.

d. Menjadi lebih sensitif terhadap aransemen spatial akibat pengaruh dari membayangkan sempoa dalam otak kita.

e. Untuk anak-anak yang suka lalai menghafal rumus perkalian, mental aritmatika sangat membantu.

f. Menumbuhkan rasa percaya diri dan sikap mental positif, terutama dalam menghadapi soal-soal matematika atau berhitung. 
Efektivitas merupakan sesuatu yang memberikan pengaruh tau membawa hasil yang di timbulkan dari suatu tindakan. Efektivitas adalah faktor yang sangat penting dalam pelajaran karena menentukan tingkat keberhasilan suatu metode maupun media pembelajaran yang di gunakan. Kamus Besar Bahasa Indonesia (2008), menjelaskan bahwa efektif berati ada efeknya (akibat, pengaruh atau kesan ). ${ }^{17}$

Menurut Juita (2018) berhitung di taman kanak-kanak diberikan secara bertahap, diawali dengan menghitung benda-benda ${ }^{18}$. Sedangkan menurut Jannah (2012) berhitung pada anak dialami juga melalui pengalaman peristiwa konkrit yang dialami melalui pengamatan terhadap alam sekitar dan melalui tingkat kesukarannya, misalnya dari konkrit ke abstrak, mudah ke sukar, dan dari sederhana ke yang lebih kompleks $^{19}$. Menurut Joni (2016) ada beberapa kelompok dasar berhitung yang harus di kembangkan untuk anak taman kanak-kanak yaitu: a) Mengelompokkan (classification), yaitu kemampuan anak dalam mengelompokkan suatu benda berdasarkan sesuatu. Misalnya: jenis, warna, bentuk, dan lain-lain; b) Membandingkan (comparation), yaitu kemampuan untuk membandingkan dua buah benda (objek) berdasarkan ukuran ataupun jumlahnya (kualitas); c) Mengurutkan (seration), yaitu kemampuan membandingkan ukuran atau kualitas lebih dari dua benda. Cara mengurutkannya dari paling pendek ke paling panjang; dan d) Menyimbolkan (symbolization), yaitu kemampuan dalam membuat simbol berupa: angka atau bilangan, simbol tanda operasi dari sebuah proses perhitungan. ${ }^{20}$

\footnotetext{
17 Montolalu, B. E.F, dkk. 2011. Bermain dan Permainan Anak. Jakarta: Universitas Terbuka, hal. 2

${ }^{18}$ Juita, R. (2018). Peningkatan Kemampuan Berhitung Anak Melalui Permainan Menakar Air di TK Aisyiyah Koto Kaciak Maninjau. Jurnal Pesona PAUD, 01(1).

19 Jannah, H. (2012). Bentuk Pola Asuh Orang Tua dalam Menanamkan Perilaku Moral pada Anak Usia di Kecamatan Ampek. Pesona PAUD, 1(1), 257-258.

${ }^{20}$ ibid
} 


\section{TEMUAN DAN PEMBAHASAN}

Efektivitas Penggunaan Alat Bermain Edukatif Jarimatika untuk meningkatkan Kemampuan berhitung anak usia dini di RA Baiturrahman Berdasarakan wawancara penggunaan metode jarimatika dimulai dari kegiatan awal, kegiatan inti dan kegiatan penutup atau evaluasi:

1. Kegiatan Awal

Kegiatan awal diawali dengan memberikan simulasi pada anak, pembelajaran awal dilakukan dengan melakukan kegiatan melingkar di halaman sekolah, yaitu bernyanyi, membaca do'a-do'a pendek, dan melakukan bincang-bincang dengan anak.

2. Kegiatan Inti

Kegiatan inti ini guru menjelaskan tema yang akan dipelajari dalam pembelajaraan saat itu. Untuk penggunaan metode jarimatika dapat disesuaikan dengan tema yang akan dilaksanakan, untuk Kegiatan yang pertama dalam penggunaan jarimatika pertama guru menjelaskan apa itu jarimatika, kemudian guru menjelaskan serta memberi contoh cara penggunaan metode jarimatika. Setelah anak memahami guru meberikan soal berhitung yang sangat sederhana dengan cara menghitung banyak gambar jari yang satu dan yang kedua.

Penggunaan metode jarimatika guru tidak lupa menerapkan beberapa metode seperti metode bernyanyi dan metode demonstrasi, metode tersebut disesuaikan dengan kondisi anak-anak didalam kelas, penerapan metode dalam kegiatan agar pembelajaran tidak monoton, sehingga anak akan mengikuti pembelajaran dengan baik dan sebagai dorongan agar anak tidak merasa bosan.

Manfaat dan tujuan dari tugas diatas untuk mampu mengetahui aktifitas sehari-hari dan anak dapat mengembangkan potensi yang ada pada dirinya. Setelah selesai kegiatan anak diperbolehkan untuk istirahat bermain untuk bermain di luar kelas. 
3. Kegiatan Istirahat

Sebelum anak-anak melakukan kegiatan istirahat anak-anak membaca do'a sebelum makan dan bernyayi. Dari hasil yang dilihat peneliti, sebelum anak-anak makan anak-anak mencuci tangan terlebih dahulu kemudian dilanjut Kemudian dilanjutkan dengan makan bersama, pada istirahat anak-anak dilatih agar anak mau berbagi dengan temanya sehingga kebersaamaan anak mampu terlihat. Setelah selesai makan anak-anak mencuci kembali tangannya dan setelah itu anak-anak diberi kebebasan untuk bermain di luar namun tetap dalam pengawasan guru dan wali murid.

\section{Kegiatan Penutup}

Kegiatan penutup anak kembali duduk melingkar di karpet seperti saat pembelajaran dimulai, Guru mengulas kembali pembelajaran yang telah dilakukan, dalam kegiatan penutup anak-anak diharapkan bisa menjawab pertanyaan-pertanyaan sederhana dari guru mengenai kegiatan yang telah dilaksanakan yang sesuai dengan yang telah dilakukan atau diajarkan, yang bertujuan agar dapat menilai anak apakah anak mampu menjawab pertanyaan. Kemudian guru memberi kesempatan pada anak-anak yang berani menceritakan kegiatan apasaja yang telah dilakukan dengan memberikan rewardagar anak ingin melakukan kegiatan di hari berikutnya.

Berdasarkan hasil penilaian untuk mengukur penggunaan metode jarimatika ini yang mencakup empat indikator yaitu penerapan, sarana prasarana, keterlibatan anak, dan keterlibatan guru. Hasil data yang sudah didapat saat pelaksanaan pertama dalam penggunaan alat bermain edukatif jarimatika dapat dikatakan "cukup terlaksana". Karena, terdapat beberapa faktor yang menghambat dalam proses pelaksanaannya salah satunya dalam penggunaan metode ini harus bisa menyesuaikan terlebih dahulu dengan kondisi anak-anak dan penggunaan jarimatika yang belum memenuhi kriteria. 
Pelaksanaan kedua anak sudah mampu mengikuti kegiatan dengan baik, berhitung dengan menggunakan metode jarimatika anak lebih semangat dan mampu berhitung dengan cepat tanpa mencorat-coret di bukunya, adapun guru selalu mendampingi ketika anak sedang melakukan kegiatan berhitung. Pengaruh penggunaan metode ini sangat besar untuk anak usia dini meskipun berhitung dengan angka sederhana akan tetapi anak mampu memahami cara penggunaan metode jarimatika ini, sehingga ketika anak memasuki jenjang pendidikan selanjutnya anak mampu berhitung sesuai apa yang telah di ajarkan dengan menggunakan metode tersebut. Jadi penggunaan alat permainan edukatif jarimatika ini sangat efektif untuk anak usia dini karena memudahkan anak untuk belajar berhitung.

\section{KESIMPULAN}

Efektivitas Penggunaan Alat Bermain Edukatif jari untuk meningkatkan kemampuan berhitung pada Anak Usia Dini Di RA Baiturrahman sudah terlihat baik dan mengacu pada kurikulum 2013. Untuk penerapan metode pembelajaran jarimatika ini dimulai dari perencanaan pembelajaran yang melalui beberapa tahap yaitu: Program Semester (PROSEM), Rencana Pelaksanaan Pembelajaran Mingguan (RPPM), dan Rencana Pelaksanaan Pembelajaran Harian (RPPH).

Menurut hasil data yang sudah didapat saat pelaksanaan pertama dalam penggunaan alat bermain edukatif jarimatika dapat dikatakan "cukup terlaksana". Karena, terdapat beberapa faktor yang menghambat dalam proses pelaksanaannya salah satunya dalam penggunaan metode ini harus bisa menyesuaikan terlebih dahulu dengan kondisi anak-anak dan penggunaan jarimatika yang belum memenuhi kriteria.

Efektivitas hasil selanjutnya dalam penggunaan alat permainan edukatif jarimatika sudah diterapkan dengan baik sesuai pengamatan langsung dan dapat dikatakan "terlaksana". Hasil penggunaan alat bermain edukatif jarimatika untuk meningkatkan kemampuan berhitung anak usia dini 
diperoleh saat penelitian yaitu BSH yang artinya Berkembang Sesuai Harapan, anak sudah dapat melakukan sendiri tanpa ada bantuan dari gurunya, BSB yang artinya Berkembang sangat Baik, anak sudah melakukannya secara mandiri serta dapat membantu temannya dalam melaksanakan kegiatan atau tugas.

Pada pelaksanaan selanjutnya anak sudah mampu mengikuti kegiatan dengan baik, berhitung dengan menggunakan metode jarimatika anak lebih semangat dan mampu berhitung dengan cepat tanpa mencorat-coret di bukunya, adapun guru selalu mendampingi ketika anak sedang melakukan kegiatan berhitung. Pengaruh penggunaan metode ini sangat besar untuk anak usia dini meskipun berhitung dengan angka sederhana akan tetapi anak mampu memahami cara penggunaan metode jarimatika ini, sehingga ketika anak memasuki jenjang pendidikan selanjutnya anak mampu berhitung sesuai apa yang telah di ajarkan dengan menggunakan metode tersebut. Jadi pengunaan alat permainan jarimatika sangat efektif digunakan untuk anak usia dini belajar menghitung dan sangat memudahkan anak. Berikut gambar alat permainan edukatif jarimatika dan diambil setelah menerapkan alat permainan tersebut.

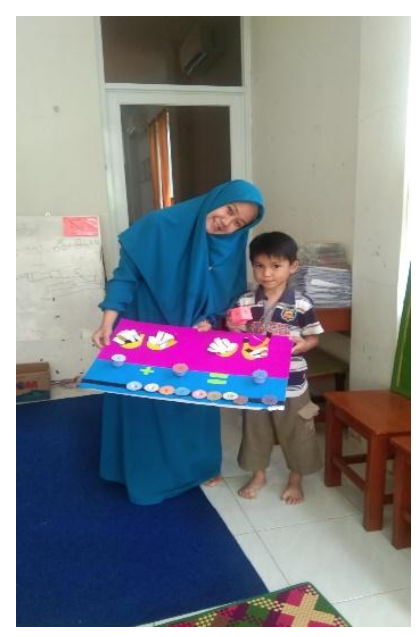


Nurlaela, Penggunaan Media Jarimatika Untuk Meningkatkan Kemampuan Berhitung Anak Usia Dini

\section{DAFTAR PUSTAKA}

Depdiknas 2007. Pedoman Permainan Berhitung Permulaan di Taman KanakKanak. Jakarta: Dirjen Dikdasmen.

Erman Suherman., dkk. 2003. Strategi Pembelajaran Matematika Kontemporer. Bandung: JICA Universitas Pendidikan Indonesia.

Husnatul Jannah. 2012. Bentuk Pola Asuh Orang Tua dalam Menanamkan Perilaku Moral pada Anak Usia di Kecamatan Ampek. Jurnal IImiah Pesona PAUD 01: 257-258.

Joni. 2016. Peningkatan Kemampuan Kognitif Anak dalam Kegiatan Berhitung dengan Permainan Dadu TK Mutiara Pekanbaru. Jurnal Obsesi Jurnal Pendidikan Anak Usia Dini 02: 1-10.

Masitoh, dkk. 2005. Strategi Pembelajaran TK. Jakarta: Universitas Terbuka.

M. Fadlillah. 2016. Penanaman Nilai-Nilai Karakter Pada Anak Usia Dini Melalui Permainan-Permainan Edukatif. Prosiding Seminar Nasional Pengintegrasian Nilai Karakter dalam Pembelajaran Kreatif di Era Masyarakat Ekonomi ASEAN 01: 1-7.

Montolalu, B. E.F, dkk. 2011. Bermain dan Permainan Anak. Jakarta: Universitas Terbuka.

Tetty Khairani Nasution., \& Edy Surya. 2015. Penerapan Teknik Jarimatika dalam Upaya Meningkatkan Kemampuan Operasi Hitung Perkalian Bilangan. Edumatica:Jurnal Pendidikan Matematika 05: 49-58.

Ninik Sulistyaningsih. 2018. Peningkatan Keaktifan Belajar Matematika dengan Strategi Pembelajaran. Jurnal Pendidikan: Riset \& Konseptual 02: 57-63.

Ratna Juita. 2018. Peningkatan Kemampuan Berhitung Anak Melalui Permainan Menakar Air di TK Aisyiyah Koto Kaciak Maninjau. Jurnal IImiah Pesona PAUD 01: 1-9.

Saifuddin Azwar. 2009. Metode Penelitian. Yogyakarta: Pustaka Pelajar. 
Slameto. 2010. Belajar dan Faktor-Faktor Yang Mempengaruhinya. Jakarta: PT. Rineka Cipta.

Sugiyono. 2014. Metode Penelitian Kuantitatif, Kualitatif, dan R\&D. Bandung: Alfabeta.

Qoyumil Hikmah., Misno A. Lathif, \& K Khutobah. 2016. Peningkatan Kemampuan Berhitung Pada Anak Kelompok B Melalui Permainan Kartu Angka di TK Dharma Indria I Kecamatan Patrang Kabupaten Jember Tahun Pelajaran 2015/2016. Jurnal Edukasi (JUKASI). 03: 39-42.

Wina Sanjaya 2013. Strategi Pembelajaran Beorientasi Standar proses Pendidikan. Jakarta: Kencana. 